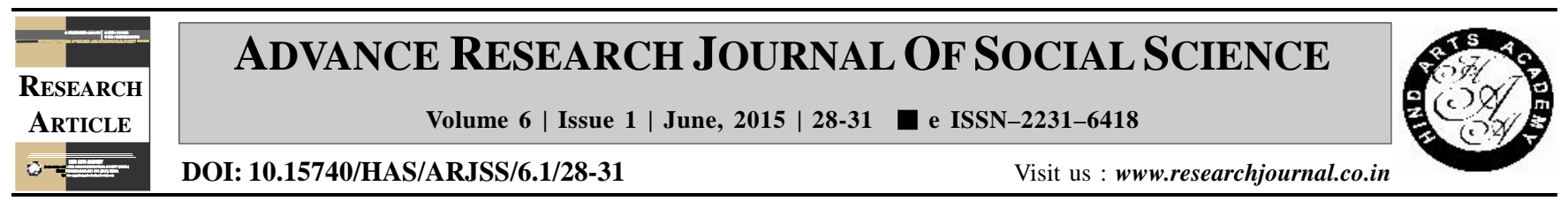

\title{
Neonatal care practices regarding traditional beliefs and customs adopted by slum families in Parbhani district
}

\author{
Anuradha Dubey* and Ramana Desetty ${ }^{1}$
}

Department of Human Development, Women's College of Home Science and BCA, Loni, AHMEDNAGAR (M.S.) INDIA

${ }^{1}$ Department of Human Development, College of Home Science, Vasantrao Naik Krishi Vidyapeeth, PARBHANI (M.S.) INDIA

\section{ARTICLE INFO :}

$\begin{array}{lll}\text { Received } & : & 09.03 .2015 \\ \text { Revised } & : & 10.04 .2015 \\ \text { Accepted } & : & 22.04 .2015\end{array}$

KEY WORDS :

Neonatal care practice, Newborn traditional practice

\section{HOW TO CITE THIS ARTICLE :}

Dubey, Anuradha and Desetty, Ramana (2015). Neonatal care practices regarding traditional beliefs and customs adopted by slum families in Parbhani district. $A d v$. Res. J. Soc. Sci., 6 (1) : 28-31.

*Author for correspondence

\begin{abstract}
Background: A human infant from time of Birth up to $28^{\text {th }}$ day of life is called a newborn or neonate. Nearly 27 million babies are born in India each year. Every year 4 million babies die in first month of life in the world and quarter of these takes place in India. Child birth and neonatal period are culturally important times during which there is strong adhere to traditional practices. The objective of this study is to identify the neonatal care practices regarding traditional beliefs and customs adopted by slum families in Parbhani town of Maharashtra.

Materials and Methods: A descriptive research design was adopted for this study. Purposive sampling method was used to select 120 samples from selected slums in Parbhani town. A close ended questionnaire was used to collect the data from the subject.

Results: The data collected from 120 families were analysed using descriptive statistics. Almost all of the mothers (98\%) have followed oil massage for baby before bath. Majority (65\%) of the mothers have provided home remedies for treating their neonates during illness. Majority of families irrespective of SES and gender had various beliefs for not feeding colostrums, for oiling sensory organs, not to feed the baby in presence of others, adding and deleting food items from mother's diet, feeding pre lacteal feeds and using ornaments and cosmetics to their neonates for many reasons.

Conclusion: Findings of the study revealed 5that there is Strong relationship between SES and cultural practices and beliefs on neonatal care among mothers. Awareness programs regarding do's and don'ts of neonatal care should be conducted in slum area which will minimize the unhealthy traditional practices.
\end{abstract}

